\title{
Behaviour of Two Storey RC Frame Subjected to Lateral Load
}

\author{
R. Anu, S. Thirugnanasambandam
}

\begin{abstract}
Reinforced concrete (RC) bare frames are being used to resist lateral loads.These frames behaviour is depending on stiffness of frames and materials used.A two storey RC bare frame with single bay is tested for lateral loading at beam column joint in each storey. The dimension of the specimen such as beam, column and exterior, interior and top corner beam - column joints were designed as per IS: 13920-1993 recommendations. The test specimen was reduced to 1/4th scale to suit the loading arrangement and test facilities. Prototype specimen had beam dimensions of $230 \mathrm{~mm} \times 350 \mathrm{~mm}$ including the slab thickness and column dimension of $300 \mathrm{~mm} \times 300 \mathrm{~mm}$. The dimensions of beam and column were made as $170 \mathrm{~mm} \times 120 \mathrm{~mm}$ and $200 \mathrm{~mm}$ $x 120 \mathrm{~mm}$ respectively. The length of the beam for the test specimen was $1200 \mathrm{~mm}$. The height of the column for test specimen was $1000 \mathrm{~mm} . \mathrm{RC}$ frame was cast, as bare frame. The $R C$ frame was subjected to lateral load and the behaviour of frames was studied till failure.Important parameters such as capacity of frame, energy absorption and ductility were determined.
\end{abstract}

Index Terms-Behaviour of frames, Lateral load, Prototype, RC frame.

\section{INTRODUCTION}

Reinforced concrete framed structures are the most common type of structures used in the modern construction field [1].RC frame consists of beams and columns. The flat plane supported on beams is called slabs.In RC frames, columns are rigidly connected with beams. The size of columns and beams are selected to suit the actual design requirements of gravity loads. The column should be strong enough than beam to ensure the safety and stability of the framed structures [2].The framed structures are classified into rigid and flexible frame structures based on fixed conditions.Generally the rigid frame structure are supported by fixed supports and the flexible framed structures are supported by pinned supports. The RC framed structures are more beneficial than the load bearing structures in many ways such as economical, ease in construction, more floor area, more lateral resistant, easy for alternation work. The load bearing structures will have higher damage to lateral loads such as wind loads, earthquake loads, blast loads compared to $\mathrm{RC}$ framed structures. The main aim of this study is to outcome the behaviour of $\mathrm{RC}$ walls against lateral loadings.Generally the lateral loads will have serious effects on structures than the gravity loadings such as dead load and vertical imposed loadings.

Revised Manuscript Received on April 12, 2019.

R. Anu,Research Scholar, Department of Civil and Structural Engineering, Annamalai University, Annamalainagar608002.(anuravichandran17@gmail.com)

S. Thirugnanasambandam,Associate Professor, Department of Civil and Structural Engineering, Annamalai University, Annamalainagar608002 (agstsai@gmail.com)

\section{PREPARATION OF MODEL FRAME STRUCTURE}

\section{Materials used for casting model frame}

Materials were chosen based on the IS stipulations.53 grade Ordinary Portland Cement (OPC) was used as binding materials with a specific gravity of 3.15 .The specific gravity of fine aggregate and coarse aggregate are 2.68 and 2.7 respectively.A super plasticizer is used to enhance the workability of concrete.The mix proportion was designed for M30 grade with a mix ratio of 1: 2.12: 3.37 [3].The w/c ratio is taken as $0.47 \%$. The dimensions of the beams and columns are $170 \mathrm{x} 120 \mathrm{~mm}$ and $200 \mathrm{x} 120 \mathrm{~mm}$ respectively. The height of the frame model is $2.84 \mathrm{~m}$ and the width of the frame is $1.2 \mathrm{~m}$. The frame was cast in the laboratory and it was under water curing for 28 days continuously.After completion of curing period the frame was tested under lateral loading conditions.Fig. 1 shows the casting and curing of reinforced concrete frame model.

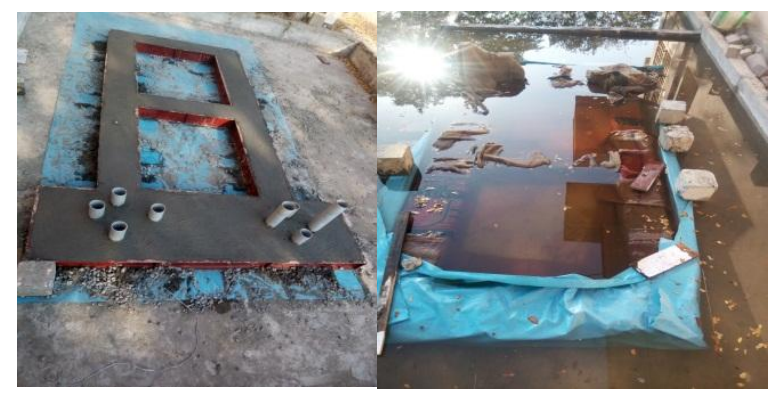

Fig.1Casting and curing of RC frame model

\section{Loading setup for frame model}

The prototype of the RC frame is reduced to $1 / 4^{\text {th }}$ scale. The test setup for bare frame is shown in Fig. 2.It consists of loading arrangement and instrumentation for measuring deflection.Load points were located at top-storey levels in line with the beams [4].The frame which is used for the loading arrangements was fixedrigidly to the test floor.Loading jacks of 25 Ton capacity were placed at the each storey levels.Lateral load was applied through hydraulic jacks and the corresponding lateral displacement was measured by Linear Variable Differential Transducers (LVDT).The least count of these LVDT's is $0.01 \mathrm{~mm}$. 


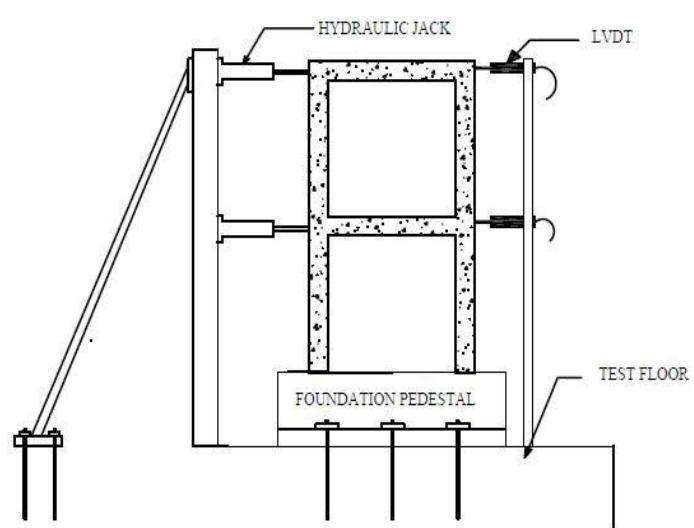

Fig.2 Test Setup of RC Frame Model

Proper care was taken to avoid displacements due to rotation of frame from pedestal and the foundation block used to arrest the rotation of the frame with respect to test floor the testing of RC frame as shown in Fig.3.

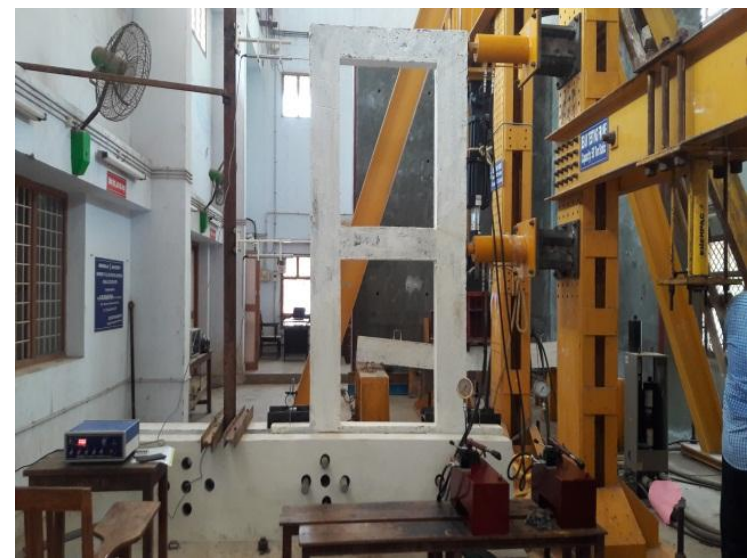

Fig.3Testing of RC Frame Model

The loading sequence of the frame was $0,15,30,45$ kNupto $82.52 \mathrm{kN}$ and $0,12,24,36 \mathrm{kNupto} 66 \mathrm{kN}$.At the end of each increment of load, the deflection values were noted.The Linear Variable Differential Transducers were connected at the opposite end of the frame loading point to measure the displacement.LVDT were used at the beam column joint in line with the beam member.Two LVDT were used to measure the lateral deflection at bottom and top storey for push and pull type lateral loading conditions.The Fig.4 shows the RC frame model after testing under lateral loading conditions. The crack patterns are shown in Fig.5-6

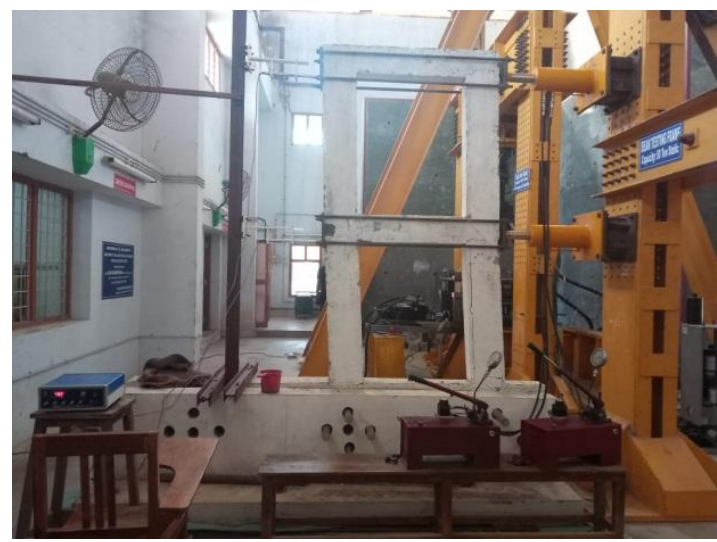

Fig.4Testing of RC Frame Model

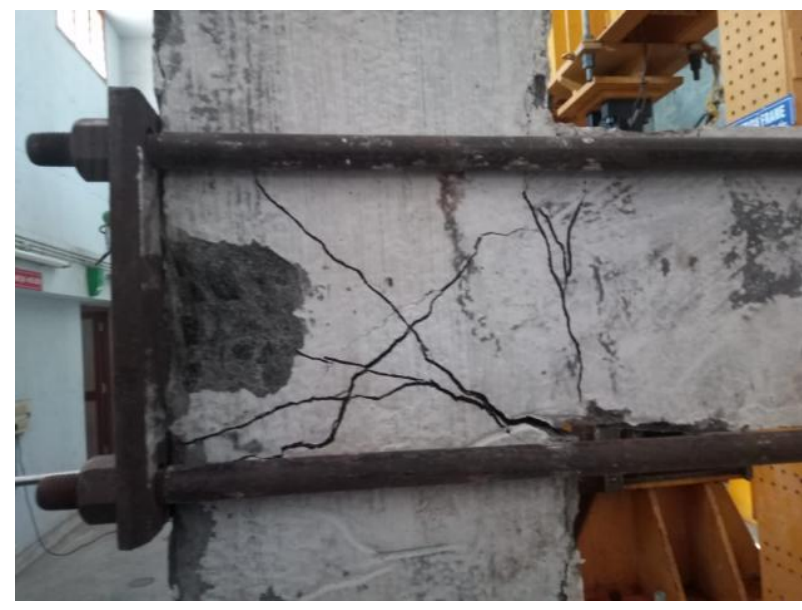

Fig.5Crack pattern at beam column joint at the opposite to loading end

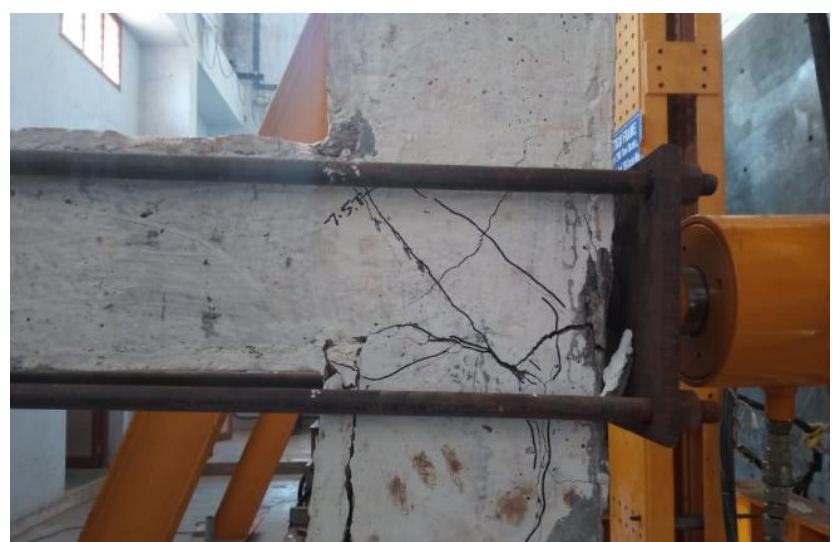

Fig.6Crack pattern at beam column joint at loading end

\section{EXPERIMENTAL INVESTIGATIONS}

The displacements measured at each lateral load level for push and pull conditions are given in Table 1.The load versus corresponding displacement curve was plotted as shown in Fig.7 - 10. These values are used to draw the load - displacement at each storey level of RC frame.The crack at yield point load was found to be $15 \mathrm{kN}$ and the corresponding deflection is $8 \mathrm{~mm}$ for pushing load at bottom storey.The crack at the yield point load was found to be 12 $\mathrm{kN}$ and the corresponding deflection was $9 \mathrm{~mm}$ at bottom storey.The crack at ultimate was found to be $82.50 \mathrm{kN}$ and the corresponding deflection is $49 \mathrm{~mm}$ for pushing load at bottom storey. The crack at the ultimate load was found to be $66 \mathrm{kN}$ and the corresponding deflection was $62.30 \mathrm{~mm}$ for pulling load at bottom storey. The crack at yield point load was found to be $15 \mathrm{kN}$ and the corresponding deflection is $11 \mathrm{~mm}$ for pushing load at top storey.The crack at the yield point load was found to be $12 \mathrm{kN}$ and the corresponding deflection was $12 \mathrm{~mm}$ for pulling at top storey.The crack at ultimate was found to be $82.50 \mathrm{kN}$ and the corresponding deflection is $68.30 \mathrm{~mm}$ for pushing load at top storey.The crack at the ultimate load was found to be $66 \mathrm{kN}$ and the corresponding deflection was $69.35 \mathrm{~mm}$ for pulling load at top storey.

Published By:

Blue Eyes Intelligence Engineering 
Table 1 Load - Displacement behaviour of RC frame model

\begin{tabular}{|c|c|c|c|c|c|c|}
\hline \multirow{2}{*}{$\begin{array}{c}\text { SI. } \\
\text { NO }\end{array}$} & \multicolumn{2}{|c|}{ Load (kN) } & \multicolumn{4}{c|}{ Deflection (mm) } \\
\cline { 2 - 7 } & \multirow{2}{*}{ Push } & \multirow{2}{*}{ Pull } & \multicolumn{2}{c|}{ Bottom Storey } & \multicolumn{2}{c|}{ Top storey } \\
\cline { 4 - 7 } & & & Push & Pull & Push & Pull \\
\hline 1 & 0 & 0 & 0 & 0 & 0 & 0 \\
\hline 2 & 15 & 12 & 8.00 & 9.00 & 11.00 & 12.00 \\
\hline 3 & 30 & 24 & 16.00 & 20.00 & 26.40 & 28.30 \\
\hline 4 & 45 & 36 & 27.00 & 33.30 & 39.40 & 41.60 \\
\hline 5 & 60 & 48 & 36.00 & 44.60 & 51.30 & 53.60 \\
\hline 6 & 75 & 60 & 44.90 & 56.30 & 62.30 & 64.30 \\
\hline 7 & 82.5 & 66 & 49.0 & 62.30 & 68.30 & 69.35 \\
\hline
\end{tabular}

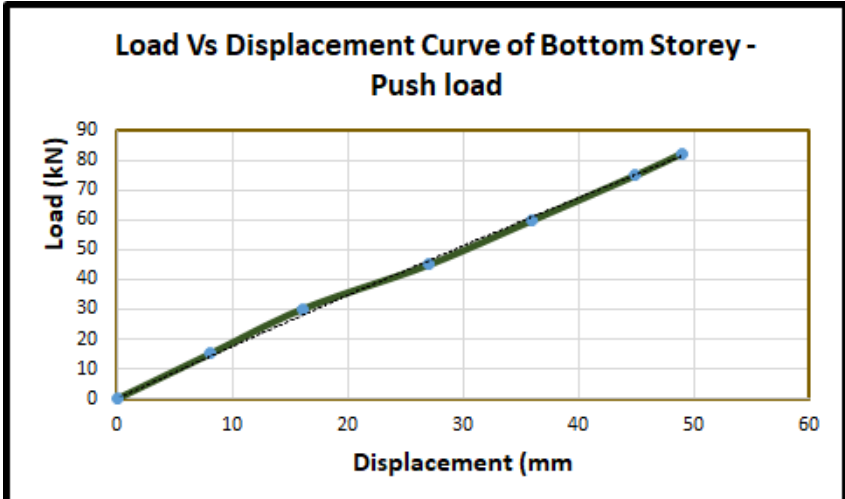

Fig.7Load Vs Displacement curve for RC frame for bottom storey - Push type loading

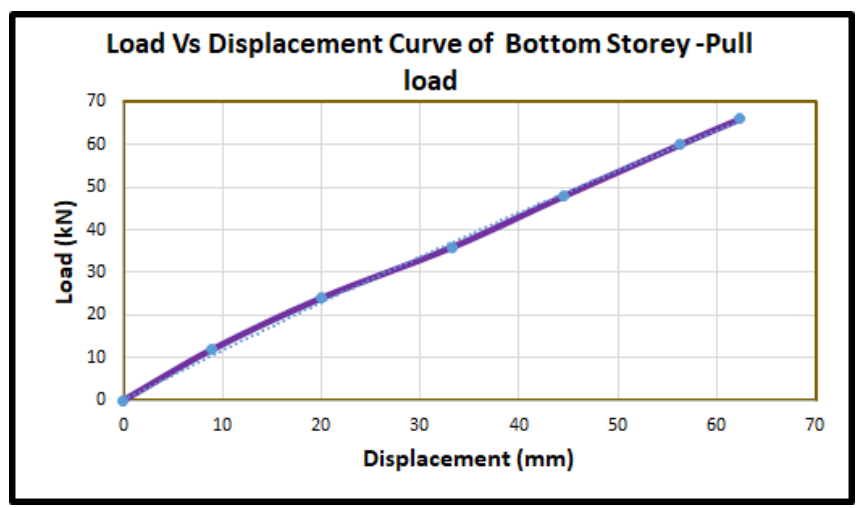

Fig.8Load Vs Displacement curve for RC frame for bottom storey - Pull type loading

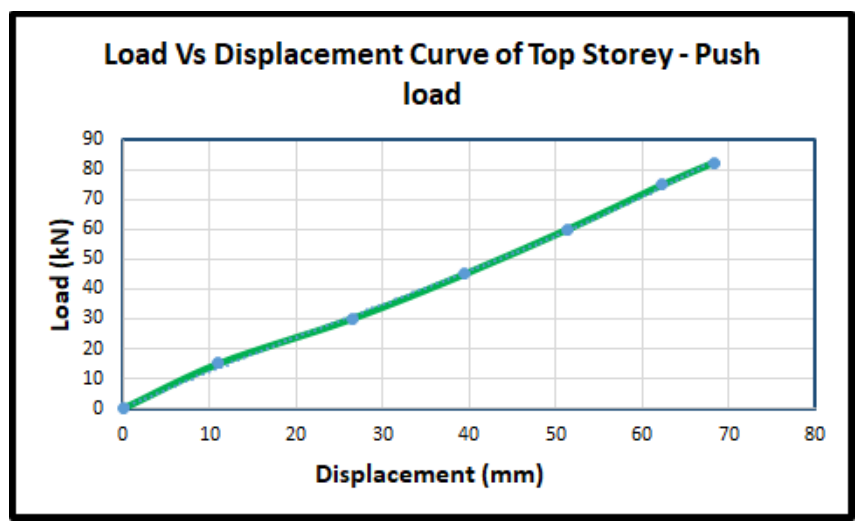

Fig.9Load Vs Displacement curve for RC frame for Top storey - Push type loading

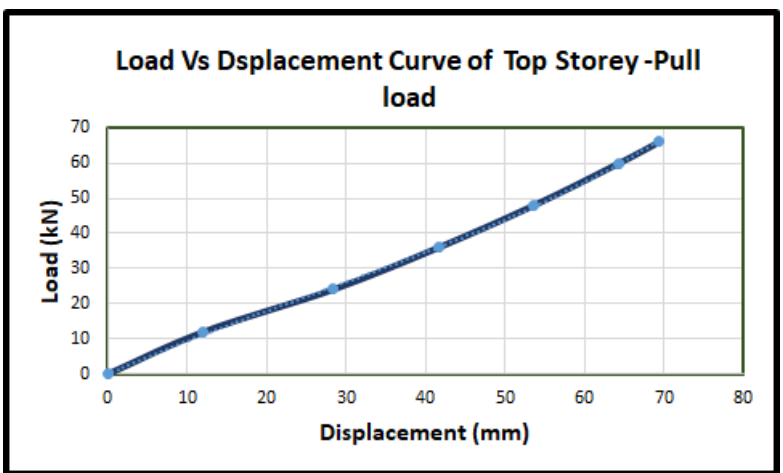

Fig.10Load Vs Displacement curve for RC frame for Top storey - Pull type loading

\section{RESULTS AND DISCUSSIONS}

The behaviour of RC frame model under lateral loading conditions are obtained from the experimental investigations and the results are presented.The stiffness characteristics of RC bare frame at each storey level is calculated and compared in Fig.11.The slope of initial tangent (dy/dx) is calculated as stiffness of frame.The ductility characteristics of RC bare frame at each storey level is calculated and compared in Fig. 12.The ductility factor is the ratio between displacement at ultimate load and displacement at yield load.The energy absorption capacity characteristics is founded at each storey and compared in Fig. 13.The area under load - displacement curve is calculated as energy absorption capacity of RC bare frame [5].The stiffness and ductility characteristics of the top storey is higher than the bottom storey. The energy absorption capacity of the bottom storey is higher than the top storey.

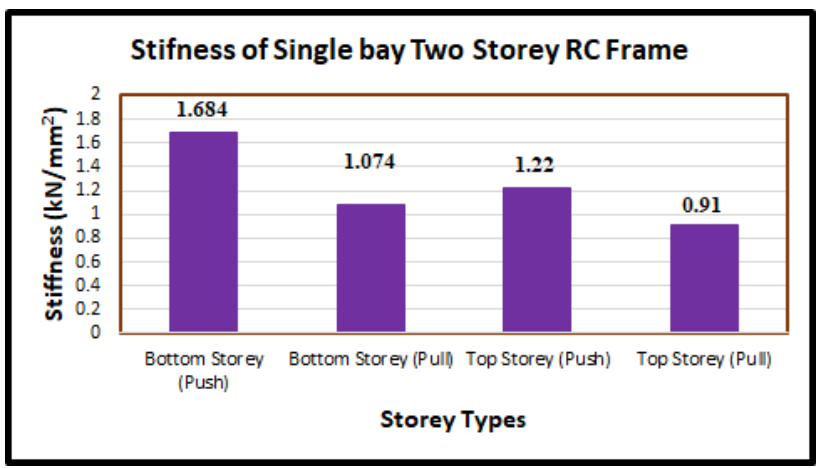

Fig.11 Stiffness characteristics of RC frame model

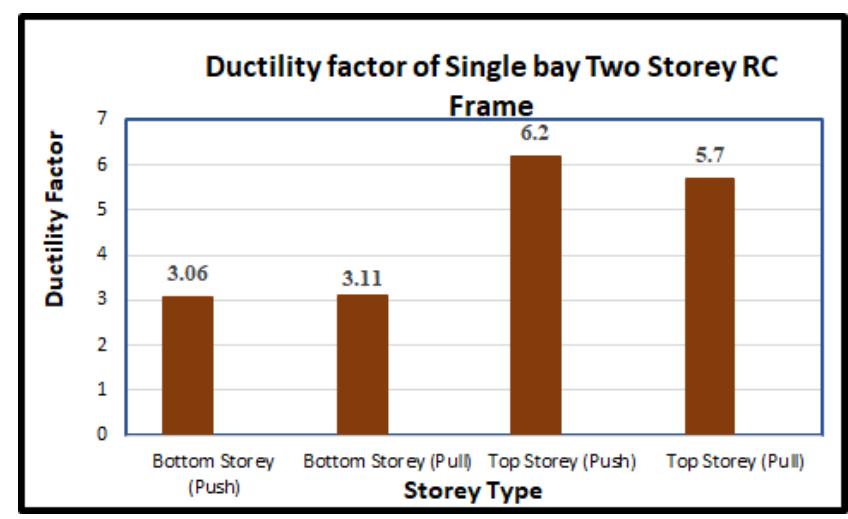

Fig.12 Ductility characteristics of RC frame model

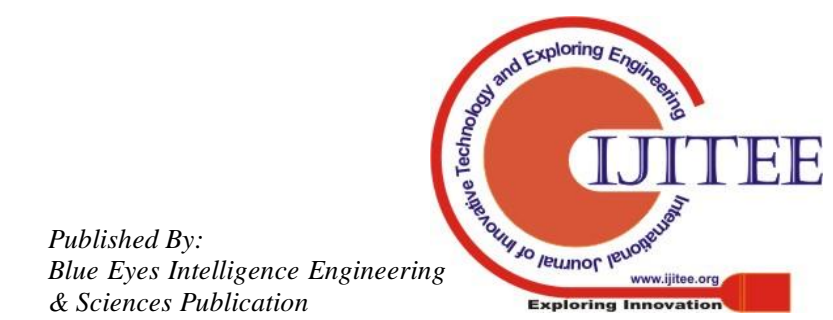




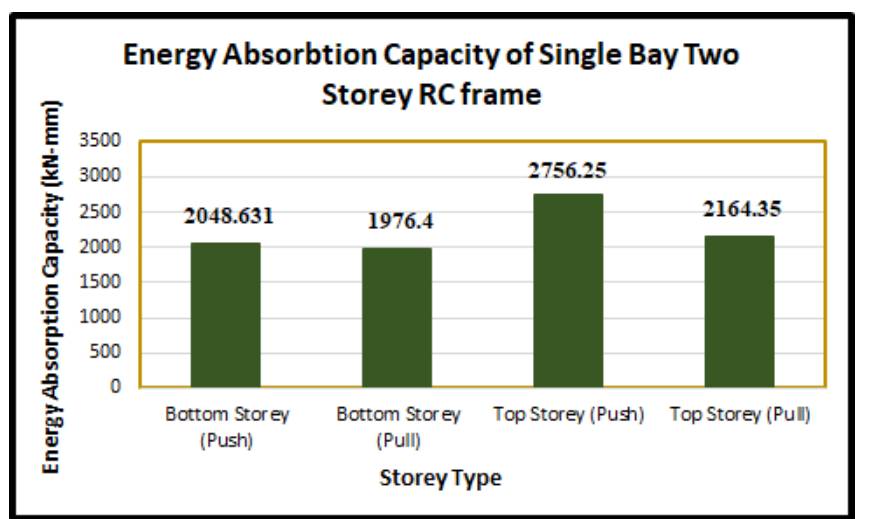

Fig.13 Energy absorption capacity of RC frame model

\section{CONCLUSIONS}

The following conclusions are made from this thesis work.

1. The suitable materials for conducting experiment are found and collected from the locally available market.Preliminary tests are conducted for cement, fine and coarse aggregate. The specific gravity of cement, sand and coarse aggregate are found as 3.15, 2.68, and 2.7 respectively.From the sieve analysis of fine aggregate, zone and fineness modulus are obtained as II and 2.89 respectively.Fine modulus of coarse aggregate is found as 6.73 .

2. M30 grade mix is selected for casting $\mathrm{RC}$ frame and mix proportion obtained using IS 10262 - 2009. The mix proportion is $1: 2.12: 3.37$ with w/c ratio of 0.47 . To get workable concrete, super plasticizer of dosage $0.4 \%$ is added to concrete.It is found that, the slump of the concrete is $55 \mathrm{~mm}$.Compressive strength $150 \mathrm{~mm}$ cubes is obtained as $31.67,36.26$ and $38.60 \mathrm{~N} / \mathrm{mm}^{2}$ at 7 , 14 and 28 days respectively.

3. The RC bare frame ultimate lateral load capacity at each storey level is found as $82.50 \mathrm{kN}$ for push loading. The maximum displacement corresponding to this ultimate load is $49.00 \mathrm{~mm}$ and $68.30 \mathrm{~mm}$ at bottom and top storeylevel respectively.

4. The RC bare frame ultimate lateral load capacity at each storey level is found as $66 \mathrm{kN}$ for pull loading.The maximum displacement corresponding to this ultimate load is $62.30 \mathrm{~mm}$ and $69.35 \mathrm{~mm}$ at bottom and top storey level respectively.

5. The stiffness of the bottom storey and thetop storey level of RC bare frame for push type loading is $1.68 \mathrm{kN} / \mathrm{mm}$ and $1.22 \mathrm{kN} / \mathrm{mm}$ respectively.

6. The stiffness bottom storey and top storey level of RC bare frame for pull type loading is $1.07 \mathrm{kN} / \mathrm{mm}$ and 0.91 $\mathrm{kN} / \mathrm{mm}$ respectively.

7. The ductility factor at the bottom storey and the top storey level of RC bare frame under push type loading are 3.06 and 6.20 respectively.

8. The ductility factor at thebottom storey and the top storey level of RC bare frame under pull type loading are 3.11 and 5.70 respectively.

9. The energy absorption capacity of the bottom storey and the top storeylevel for push type loadings are $2048.63 \mathrm{kN}-\mathrm{mm}$ and $2756.25 \mathrm{kN}-\mathrm{mm}$ respectively.
10. The energy absorption and the bottom storey and the top storeylevel for pull typeloadings are $1976.40 \mathrm{kN}$ $\mathrm{mm}$ and $2164.35 \mathrm{kN}-\mathrm{mm}$ respectively.

\section{REFERENCES}

[1] OviduiBolea, "The seismic behaviour of reinforced concrete structures with infill masonry in the bucharest area",Sustainable Solutions for Energy and Environment, EENVIRO - YRC 2015, pp. 60-76, Energy procedia 85, Elsevier, 18-20 November 2015, Bucharest, Romania

[2] C.V.R Murthy, "Earthquake tips - Learning earthquake design and consideration", information center of earthquake engineering- Indian Institute of Technology, Kanpur September 2005.

[3] IS 10262 - 2009, Concrete mix proportioning - Guidelines, first revision, BIS, New Delhi, India.

[4] N. Jayaramappa "'Study on the behaviour of RC frame for lateral load", International journal of engineering research \& technology, ISSn: $2278-0181$, Vol. 4, issue 05, pp. 781-788, May 2015.

[5] K. Kalaipandian and R. Amuthaselvakumar. "Sesmicbehaviour of RC frame with and without masonry infill", International journal of engineering and technology, eISSN: $2395-0056$, p-ISSN: $2395-0072$, Vol. 3, issue 05, pp. $2139-2144$, May 2016.

\section{BIOGRAPHY}

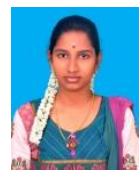

R. Anu,is doing her Ph.D., Department of Civiland Structural Engineering, Annamalai University.She had completed her Master Degree in Annamalai University.She had published 02 research papers and attended some National \& International Conference.

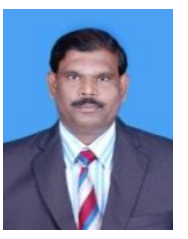

Dr. S. Thirugnanasambandam is presently working as Associate Professor in Annamalai University.He had completed his Master Degree and Doctoral Degree in Annamalai University.He is working in the Department of Civil and Structural Engineering since 1999. Four of his scholars awarded Ph.D., degree and presently guiding seven Ph.D., Scholars.He had published 74 research papers and attended many National and International Conference.His areas of interest are damage assessment and repair of structures.Also, he is familiar in development of Geopolymer concrete products. 